\title{
EMOTIONAL COMPONENT OF UNIVERSITY STUDENTS' PROFESSIONAL CONSCIOUSNESS IN THE PRESENT-DAY MEDIA DISCOURSE SPACE
}

\author{
Alla V. Guslyakova \\ RUDN University (Moscow, Russia) \\ Moscow State Pedagogical University (Moscow, Russia) \\ aguslyakova@bk.ru \\ Nina I. Guslyakova \\ South Ural State Humanitarian Pedagogical University (Chelyabinsk, Russia) \\ guslyakovani@rambler.ru
}

\begin{abstract}
The emotional component of the university students' professional consciousness is a reflection of the subjects' attitude towards their academic and professional activity, to themselves as future specialists, or to individual professionally significant aspects of their personality and activity.

Affective (emotional) structures play a crucial role in the individual's consciousness as they correlate with cognitive mechanisms of human consciousness and build "a unified system or unity of affect and intellect". Affective components of consciousness consist of emotions, moods, feelings and possess a number of functions that define success and efficiency of the individual's activity: evaluation and prompting functions, regulating and synthesizing functions, expressive, activation and signal functions.

It is essential to mention that successfully managing the affective component of university students' consciousness may define their attitude towards the whole academic process, their future career and life itself. Contemporary media discourse environment that people are living in today, no doubt, makes an impact on young people's affects, emotions and values. Therefore, the main aim of this research is to identify and evaluate how far the present-day media world influences the emotional component of students' consciousness, whether this impact changes young people's attitude towards their education and career goals and which affects and emotions students experience when referring to the space of media discourse in search of knowledge related to professional issues.

The experiment, conducted by the authors of this paper, has covered university students of three higher education institutions - Moscow State Pedagogical University, RUDN University and South Ural State Humanitarian Pedagogical University in two regions of Russian Federation (Moscow and Chelyabinsk regions) which also helped to see the similarities and differences in the young people's affective perception of their academic and professional achievements through the prism of the new media discourse environment. Recommendations on how to handle the emotional and value components of students' consciousness (while teaching them at the university) were suggested in the conclusion of the research.
\end{abstract}

Keywords: emotional component of consciousness, university students, media discourse space, education, academic and professional achievements, emotions, values.

\section{INTRODUCTION}

Emotions are an important part of human consciousness especially when people perceive and respond to the environment surrounding them. Some scholars believe that our consciousness is probably more a question of feeling than of thinking and that the individual's mind begins with the experience of the body and the world, and does not necessarily involve understanding or analyzing what exactly is being experienced.

According to C.E. Izard, in the human mind there is a huge connection between emotions (affects) and cognitive structures and operations of consciousness "thanks to the 
interaction of emotions with perceptual and cognitive functions and processes" [Izard, 1991; 1993].

In modern Russian and foreign psychology, there is special interest in studying the emotional sphere of young individuals, especially university students (G.D. Babushkin, R. Burns, V.N. Kolesnikov, N.V. Klyueva, L.V. Menshikova, V.S. Merlin, L.M. Mitina, A.A. Rean, K. Rogers, A.E. Steinmetz and others) [Guslyakova, 2013]. Emotions are ubiquitous in educational and vocational settings, and they profoundly affect students' academic and professional engagement and performance. This is particularly true in the contemporary world of the new digital media reality which, in our opinion, intensifies young people's affective engagement into the development of their professional consciousness owing to the specific media features and ways of their presentation [Guslyakova, 2016, p. 168-184].

Therefore, the main purpose of our research is to analyze the role of university students' emotional side of professional consciousness and how it is being developed under the roundthe-clock influence of the new media discourse environment.

We suggest that the modern new digital space can provide quite a strong emotional connection between the university students' strive for becoming a good professional in their chosen field and young people's reference towards the new media world for different academic and professional reasons.

\section{PROFESSIONAL CONSCIOUSNESS AND ITS EMOTIONAL SIDE}

The emotional component of professional consciousness is a reflection of the person's attitude either as a whole to their professional activities, to themselves as a future specialist, or to individual professionally significant aspects of their personality and activity. Mastering professional knowledge, norms and values, the future specialist perceives certain experiences and feelings.

The emotional component of professional consciousness appears as a complex formation, characterized by numerous links with the personality features of the subject. The content-related components of the affective sphere of a university student's professional consciousness are professional interest, self-attitude, self-esteem, emotional stability and empathy as professionally significant personal qualities. Emotional processes, affecting the activity and participating in the formation and development of functional states, are inextricably linked with volitional processes and behaviour.

Analysis of the relationship between emotional and mental processes leads us to the conclusion about the important role of emotions in such aspects of consciousness as selfconsciousness, self-identity and professional consciousness. It is important to mention that interest is the most often experienced positive emotion that motivates learning, development of skills and abilities, and creative aspirations. Professional interest in the future career affects the students' awareness of themselves in the system of academic and vocational activities, in the system of professional communication and in the system of their own personality. The formation of professional interest contributes to the positive attitude of the student to the chosen specialty, his/her gradual and painless inclusion in the independent educational activities [Teslya, 2000, p. 58-62]. Interest in an individual's work is an important condition for the development of professional abilities, and hence professional consciousness. Practice shows that if a student has chosen a profession and fallen in love with it, then, of course, he/she will strive to acquire and develop knowledge and skills, and later, try to implement them in his/her work. The growth of professional interest is carried out simultaneously with the development of professional consciousness and self-awareness.

As the most important factor, shaping the emotional and axiological attitude of the individual to him-/herself at the university stage of professional training should indicate, above all, academic and professional activities. Moreover, the affective component of young people's 
professional consciousness at a university stage of their training should be perceived as a result of the young individual's social development. The essence of the affective component of the person's professional consciousness is revealed through its connection with educational, professional and public activities and through the attitude of the individual to the surrounding reality. Taking into account that the modern reality people exist nowadays in is closely related to the new media digital world, it is reasonable to suggest that university students' professional consciousness and its affective structure are interacting with the space of a new media discourse and they become more and more interdependent on each other.

\section{UNIVERSITY STUDENTS' EMOTIONAL VALUE OF THE FUTURE PROFESSION IN THE PRESENT-DAY MEDIA DISCOURSE SPACE}

It is a true fact that the new media discourse environment plays a huge role in the present-day global society. It influences public opinions and the way people think and behave; what people watch and listen to. Ideally, the role of the media is to report the news factually and without bias. In reality, by choosing what to report and how to report what they do, they actually create news, shape the course of events as well as people's minds. In our opinion, the role of the new media discourse space in the $21^{\text {st }}$ century is to encourage people in every field of life, and it is especially true about the younger generation. This is because their minds are much more sensitive towards the interactive digital technological changes and challenges of the new millennium [Deijk, 2008; Croteau \& Hoynes, 2014]. Moreover, these challenges are intensified because technological innovations are constantly being popularized, especially among university students [Guslyakova \& Guslyakova, 2016].

Previous studies of the influence of the new media discourse space on college students' academic and professional life have identified a negative association between young people's reference towards the new media and their academic performance [Wade, Jacobsen \& Forste, p. 275-281].

The reason scholars came to such a conclusion lays in the fact that previous studies were more focused on measuring estimate time spent by young individuals in the digital media environment, like hours spent watching TV during a "typical day" [Lievrouw \& Livingstone, 2006]. On the other hand, previous studies have conceptualized electronic media as a filler for "unstructured time", a leisure activity occupying time not filled with organized activities such as class, work, and so on. However, another group of researchers, whose viewpoint we support, also suggest that our society is being more and more mediated, which means that people get most of the information through mass media, so media communication can be a very effective and powerful tool for implementing any interests [Kosáros et al., 2008, p. 79-90], including young people's positive emotional association with their higher education and future careerbuilding.

Probably, this is the most intriguing part of the present-day media environment, which is their ability to 'play' with human emotions, although they do not have emotions themselves [Doeveling \& Konijn, 2010]. What is most striking is that the new media today are reaching millions of people simultaneously and have at their disposal a vast array of technical opportunities to portray, broadcast and potentially elicit emotions on an unprecedented large scale. Modern new media discourse environment has a great potential to arouse and shape emotions. In doing so they have one thing in common: they not only convey knowledge and information about people, events or products, but they also make us feel frightened, sad, anxious, angry or happy about this phenomenon.

Research on affects received a huge increase in scholarly attention, starting in the 1980s with a steep increase in psychological studies and theoretical analyses of human emotions [Frijda, 1986] gradually spreading to related fields such as sociology, political science, anthropology, mass communication and cultural studies among others. Especially, in the 
emerging field of media psychology, studying the role of emotions in the new media has become an important topic and gradually increases our more in-depth insights into mediated communication processes [Nabi \& Worth, 2008]. Therefore, one should make scientific attempts to perceive and analyze how far the new media discourse space is able to influence young people's emotional component of consciousness when they choose their future profession. The first reason is the global digitalization of the working process at the present moment. No matter which future profession a student is going to choose, in most situations he/she will have to work in the media environment. Secondly, the new media discourse space provides young people with evaluative information about their education, academic performance, career-building, job vacancies and recruitment. When analyzing this information flow, young people usually react emotionally to the stories, facts and findings they receive, discover or read. As a good example of the media influence on young individuals' affective side of their professional consciousness one can take the new American romantic comedy "Second act" (2018) which stars Jennifer Lopez and follows a woman in her 40s who pursues a second chance at a corporate career after a friend provides her with a fake resume and credentials. The main heroine - Maya Vargas - is a long-suffering associate at a Queens bigbox store who feels like she will never be able to make anything of herself because she never went to college. The film sends an emotional message to the younger generation about the reason they need to go to the university and obtain a degree there and how to build their future career successfully and confront all the intricacies and difficulties of the modern corporate business world.

To sum up, the present-day media discourse space may become an effective mediator between university students' professional consciousness, their academic and professional preferences and the emotional response students produce when dealing with the information related to their career in the contemporary media world.

\section{METHODS AND RESULTS}

Examining emotional experiences of professional consciousness in relation to the new media discourse space is a vast and growing area of research. Therefore, to estimate university students' affective component of their professional consciousness through the perspective of the new media discourse environment, we developed a special survey and interviewed 61 bachelor students from three higher education institutions (Moscow State Pedagogical University, RUDN University (Moscow), South Ural State Humanitarian Pedagogical University (Chelyabinsk)). The survey covered such questions as whether young people's professional development is impossible without modern digital technologies; how often our respondents refer to the new media space for some professional advice; if students have their favorite media resources that help them in their academic and professional performance. We also asked our respondents about the feeling they experience when interacting with the new media environment and about their emotions in case they heard the news about media and the Internet being blocked and banned the following day.

In general, $70 \%$ of university students believe that their professional development is impossible without the support of the new media discourse environment. 55\% of our respondents mentioned that they address the Internet and other media resources to ask for their professional advice. $45 \%$ of young individuals also have their favorite media resources which help them solve life and professional problems. Table 1 demonstrates the basic feelings and emotions that our respondents experience when interacting with the new media discourse environment. 


\begin{tabular}{|c|c|}
\hline & Interest \\
& Curiosity \\
University students' basic feelings & Impatience \\
and emotions & Desire to discover something new \\
& Satisfaction \\
& Necessity \\
& Enjoyment \\
& Enthusiasm \\
\hline
\end{tabular}

Table 1. University students' feelings and emotions while interacting with the new media environment

The top three feelings and emotions young people experience when dealing with the new media discourse space on an academic and professional basis are interest $(45 \%$ of the respondents), curiosity (30\%) and impatience (15\% of the surveyed). At the same time, young individuals mentioned their desire to discover some new, interesting and useful information related to their academic and career spheres. In general, all our respondents feel positive about interacting with the new media discourse environment for academic, scientific and professional reasons. That is why, when we asked students what emotions they would experience if suddenly the new media space and the Internet stopped working, 50\% of respondents said about shock, $25 \%$ of young individuals mentioned terror, $15 \%$ of students would feel stress. Other feelings and emotions mentioned by our respondents are introduced in table 2 below.

\begin{tabular}{|c|c|}
\hline & Shock \\
& Terror \\
& Stress \\
& Interest "why?" \\
& Surprise \\
and emotions & Fear \\
& Sadness \\
& Anger \\
& Indifference \\
& Disappointment \\
& Boredom \\
\hline
\end{tabular}

Table 2. University students' feelings and emotions while hearing information about the new media and the Internet being banned and blocked

It is also interesting to notice that university students feel positive about being members of different academic and professional groups in the new media discourse space. $35 \%$ of respondents belong to their university groups and chats; volunteering groups; professional communities as well as ecological forums. Young individuals describe the present-day media environment as "quick, simple, functional, accessible, comfortable, understandable, mobile and time saving". That is why $90 \%$ of respondents consider the present-day media and the Internet to have become an integral part of their academic and professional life. Furthermore, $65 \%$ of the interviewed students experience the feeling of satisfaction when solving educational and vocational problems by means of the new media discourse resources.

To sum up, we may conclude that university students' professional consciousness is deeply integrated into the contemporary new media discourse environment and is characterized by a wide spectrum of emotions beginning with stress or disappointment if there is no access 
to the digital media discourse space and ending with the feeling of satisfaction, interest and enthusiasm when the new media technologies help to solve certain professional tasks or problems.

\section{CONCLUSIONS AND DISCUSSION}

The new media discourse space is no longer merely another tool that people use, but rather the environment within which they operate and live [Benski \& Fisher, 2013; Thurlow \& Mroczek, 2011]. This is especially true when we think about young people who have become emotionally attached to the digital world, both in their personal, academic and professional lives. Therefore, the question of media and emotions is an enduring issue and it has become more acute, because the present-day media environment allows for more elaborate modes of sharing, communication, performance, and display - all are key ingredients of emotions.

Our findings provide a perspective of the impact that the new media discourse space has on the emotional side of university students' professional consciousness. The affective component of human consciousness includes the subjective experience of situations which is connected to the feelings of arousal, pleasure, or dissatisfaction. It is discovered that young individuals' professional consciousness has become incorporated into the digital, technological environment of the contemporary new media, and while interacting with the new media discourse space due to various academic and professional issues, students always react emotionally within the process of this virtual communication.

It is found out that such positive emotions as interest, curiosity and impatience to look for necessary academic or professional information are the key affects that university students experience in the new media discourse environment. Once they face the disconnection from the digital media world for different reasons, young individuals may feel stress, shock, dissatisfaction and disappointment. Thus, we may conclude that university students' professional consciousness has become "digitalized" and possesses a two-polar set of emotions. Positive affects appear at the moment of young person's purposeful connection with the new media resources, while negative ones may occur in case a student is not able to reach the media discourse space for his/her academic, scientific or professional reasons.

Taking into account such emotional intensity of university students in their relation to the new media world, we believe that nowadays academic institutions should focus more on developing professional courses based on media platforms. Such a concept will allow lecturers and academicians to collaborate more effectively with their students, better understand young individuals' professional goals and expectations and learn to manage and monitor the educational process in institutions of higher education at the present time of the technological, virtual revolution.

\section{REFERENCES}

1. Benski, T., \& Fisher, E. (2013). Internet and emotions. Routledge Studies in Science, Technology and Society.

2. Croteau, D., \& Hoynes, W. (2014). Media and society. Industries, images, and audiences. $5^{\text {th }}$ edition. Sage Publications.

3. Dejk, T. van. (2008). Discourse and power. Contributions to critical discourse studies. Houndsmills: Palgrave MacMillan.

4. Doeveling, K. \& Konijn, E.A. (2010). The Routledge handbook of emotions and experience. London: Routledge, Taylor \& Francis.

5. Frijda, N.H. (1986). The emotions. Cambridge: Cambridge University Press.

6. Guslyakova, A. (2016). Introducing a model of information integration in the presentday mass media. $6^{\text {th }}$ International conference on science and technology. London: SCIEURO, 2, 168-184. 
7. Guslyakova, A., \& Guslyakova, N. (2016). Media discourse space impact on the professional development of undergraduate and graduate students. EDULEARN16 Proceedings. Barcelona: IATED, 6839-6846.

8. Guslyakova, N. (2013). Professional'noe soznanie uchitelja: psihologicheskij aspekt [Teacher's professional consciousness: a psychological approach]. Chelyabinsk: Izdatel'stvo CSPU (in Russian).

9. Izard, C. (1977). Human emotions. New York: Plenum.

10. Izard, C. (1991). The psychology of emotions. New York: Plenum.

11. Izard, C. (1993). Face of emotion. Irvington Publishers.

12. Kosáros, A., Lakatos, G., Katona, I., Kárász, I., \& Leskó, G. (2008). Role of media in students' life and their environmental education: a survey of students aged 13 to 17 . Journal of teacher education for sustainability, 10, 79-90.

13. Lievrouw, L., \& Livingstone, S. (2006). Handbook of new media. Social shaping and social consequences of ICTs. London: Sage.

14. Nabi, R., \& Worth, W. (2008). Exploring the role of emotion in media effects: an introduction to a special issue. Media psychology, 11(1), 1-6.

15. Teslya, E.B. (2000). Formirovanie professional'nogo interesa u budushhih uchitelej [Formation of professional interest in future teachers]. Pedagogy, 7, 58-62 (in Russian).

16. Thurlow, C., \& Mroczek, K. (2011). Digital discourse: language in the new media. Oxford University Press.

17. Vygotsky, L.S. (1991). Pedagogicheskaja psihologija [Pedagogical Psychology]. Pedagogics (in Russian).

18. Wade, C., Jacobsen, B.S., \& Forste, R. (2011). The wired generation: academic and social outcomes of electronic media use among university students. Cyberpsychology, behavior and social networking, 14 (5), 275-281. 